\title{
The Role of Employee Training and Development in Achieving Organizational Objectives: A Study of Accra Technical University
}

\author{
Hilda Hammond \\ Accra Technical University \\ Ransford Quarmyne Churchill \\ Accra Technical University \\ Research and Innovation Centre
}

\begin{abstract}
Training and development is the field which is concerned with organizational activity aimed at bettering the performance of Individuals and groups in organizational setting and to achieve the set objectives of the organization. It is a combined role often called human resources development meaning the development of "Human" resources to remain competitive in the marketplace in achieving objectives. Training focuses on doing activities today to develop employees for their current jobs and development is preparing employees for future roles and responsibilities. It carries out an analysis that the objective of training and development is to creative learning organizations which ensure that employees through value addition can effectively perform their jobs, gains competitive advantage and seek self-growth: this measurable performance resulting from good training and development, shall enhance organization development. It is a process transferring information and knowledge to employers. It is equipping employers to translate that information and knowledge into practice with a view to enhancing organization effectiveness and productivity, and the quality of a management of people. It should be considered along with education policies and systems which are crucial to the development of human resources.
\end{abstract}

Keywords: Training and Development, Objectives, Organizations, Accra Technical University, Performance, Employee

\section{INTRODUCTION}

Employee training and development is a necessary tool for achieving organizational objectives. The quality of staff in every organization leads to effective progress and development of the organization and the nation as a whole, the growth of every country or organization depends on the quality of its people or human resource. Human Resource Management is the key resource in creating a quality-oriented organization. It is the process of accomplishing organizational objectives by acquiring, retaining, terminating, developing and properly using the human resources in an organization. Human Resource is the backbone of every successful business. Recent technological advancement has brought about the need for the development of human resources of the organization. Organizations can survive or perform effectively if they obtain and develop the quality and quantity of its human resource. The quality of employees and their development through training and development are major factors in determining long-term profitability of an organization. A company's most valuable resource is its people. Managers and supervisors need to protect and enrich this resource (Noe, 2006). If you hire and keep good employees, it is good policy to invest in the development of their skills, so that they can increase their productivity. The quality of employees and their development through training and education are major factors in determining long-term profitability of any organization. According to Rothwell (2001), employees frequently develop a greater sense of self-worth, dignity and well-being as they become more valuable to the firm and to society. It is 
against this background that this research was conducted to ascertain and to bring to the fore, the importance of Training and Development of staff of Accra Technical University.

\section{Training and Development}

\section{LITERATURE REVIEW}

Training and development refers to the process to obtain or transfer KSA (knowledge, skills and abilities) needed to carry out a specific activity or task; therefore, benefits of training and development both for employer and employees are strategic in nature and hence much broader. In order to meet the current and future challenges of our business, training and development assumes a wide range of learning actions, ranging from training of the employees for their present tasks and more so, knowledge sharing to improve the business horizon and customer's service. It also focuses on their career development, thus expanding individual, group and organizational effectiveness. A comprehensive training and development program helps in deliberating on the knowledge, skills and attitudes necessary to achieve organizational goals and also to create competitive advantage (Peteraf 1993). In fact, in the start of the twenty-first century Human Resource Managers have opined that one of the main challenges they are to confront had involved issues related to training and development (Stavrou, Brewster and Charalambous 2004).

\section{Training and Development and its Process}

In order to ensure that our employees are equipped with the right kind of skills, knowledge and abilities to perform their assigned tasks, training and development plays its crucial role towards the growth and success of our business. By choosing the right type of training, we ensure that our employees possess the right skills for our business, and the same need to be continuously updated in the follow up of the best and new HR practices. To meet current and future business demands, training and development process has assumed its strategic role and in this regard few studies by Stavrou et al.'s (2004) and Apospori, Nikandrou, Brewster and Papalexandris's (2008), have attained much importance as these highlight the T\&D practices in cross-national contexts. Apospori et al. (2008) had deduced that there is a considerable impact of training on organizational performance. Differently from these studies, Cunha, Morgado and Brewster (2003) were the only ones who could not determine the impact of training on organizational performance, and suggested that another study on analysis of this relationship was needed.

\section{Need of Developing the Employees}

Jackson (2002) opined that some cultural assumptions underlie human resource management with regards to developing employees: he deliberated through an example which highlighted the distinction between the hard and soft approaches on developmental aspects, appearing in the strategic HRM literature. The hard approach assumed the employees in the organizations as mere resources to achieve the objectives of the organization, whereas the soft approach viewed the employees more as valued assets capable of development (Tyson and Fell 1986; Hendry and Pettigrew 1990). The need for developing our employees is compelling because a sound Training and Development plan has its contributions to increase productivity and quality of work. The development strategy reduces staff turnover and absenteeism and also helps in improving motivation among the employees. In order to stay ahead of our competition, training and development plan must incorporate innovation and reinvention and this is only possible when training encompasses a wide range of learning actions. Therefore, an ideal training shall become part of a company-wide strategy and it must be is linked to business goals and organizational performance. 
According to Robinson (1999) development must be systematic and adequate to enable the individual perform the given task or job. Organizations develop where employees and employers have recognized training as a means of improving performance of individuals or groups. Bateman and Snell (1999) define training as teaching lower level employees how to perform their present jobs. Training is using guided experience to change employee behaviour/attitude and is the process of changing employee behaviour/attitude through some type guided experience. Human resource plays a central role in molding a company's workforce into a motivated and committed team that can help the company and its management manages change more effectively. The fact that today, employees are central to helping companies achieve competitive advantage and manage change has led to the emergence of strategic human resource management and development with strategic goals and objectives in order to improve business performance and develop organizational cultures that foster innovation and flexibility. Strategic human resource means accepting the human resource function as a strategic partner in formulating the company's strategies as well as in executing those strategies through human resource activities like recruiting, selection, training, development and rewarding.

\section{Importance of Training}

At Accra Technical University, the aim of orientation and training is to socialize new employees and to foster high level commitment and identification with values, traditions and goals. This process involves teaching employees the core values such as standing behind the institution, taking the initiative and being able to work in teams. Pratt and Bennett (1979) defined training and development as a systematic development of knowledge, skills and attitudes required by an individual to perform a given task whilst development on the other hand, refers to the acquisition of knowledge or skills to be used in possible future jobs. Development tends to be more person centered than training.

\section{The Impact of Employee Development}

Touching on the issue of employee development or human resource development, Walton (1999) has this to say, "Whereas much marketing literature talks about products and achieving sales, in terms of human resource development, we talk about identifying and satisfying learning needs". He says that human resource practioners should think about the provision of consultancy and monitoring services and conduct of training needs analysis should be considered as avenues for reaching and satisfying employees and meeting their learning needs. Over the years, human resource development function has proved to be one of the most vulnerable areas of being downsized or dispensed with when an organization is in crises or is looking for efficiency savings. One reason is that in financial terms, the provision of training and related activities has frequently been treated as one of the outgoings that can be forgone without the basic product or services of the organization being sacrificed. Training, other than basic skills training, has often been seen as a luxury, and it has proved extremely difficult to establish any tangible relationship between the cost incurred and the benefits gained especially in terms of the "bottom line". We are in an environment where the mutuality and reciprocity of the employment relationship is constantly being emphasized.

\section{Employee Development Programs: Key Components}

There is no single formula for creating an employee development program, but there are some important components that should be considered. A truly effective employee development program should include learning, career planning, goal setting, and evaluation. These areas will help the program be beneficial to the employees who utilize and to the organization that provides it. Without them, the employee development reverts back to being simply training. 
One of the main reasons learning is becoming more and more crucial is the rise of technology. Knowledge and information are moving faster than ever with the Internet and a business cannot keep up in today's world if its employees do not have access to it. Although higher education is important to prepare people to work in business, they still need a new set of skills by the time they start working (Gerbman, 2000). It becomes the responsibility of the employer to make sure people have these skills, and it must be an on-going process. When employees need information, they often need it right now and two days from now is not soon enough. Therefore, companies need to make sure people can learn anytime (Garger, 1999). For this reason, intranets and computer-based training modules are necessary. In addition to technology, Eileen Garger also cites reorganization of companies and the changing relationship between employers and employees as reasons for the move from training to learning (1999).

According to Cunniff, (2000) "knowledge is capital, for both the individual worker and the company". Organizations and individuals should value knowledge as they do money, because in today's market they go hand in hand. Individuals must value learning as much as the organization. Ralph Bates, vice president of learning and professional development for American Management Systems, Inc. out of Fairfax, Virginia, recognizes that, "the best learning is done when individuals are motivated to learn on their own" (Garger, 1999). Companies no longer feel an obligation to control and direct employees' careers, so people at all levels are taking charge of their own career management (Feldman, 2000). It is the role of companies to provide opportunities, but individuals must take the initiative to utilize those opportunities and position themselves for future career success (Garger, 1999).

Since companies can no longer guarantee employees promotions to the top, it is important that they help employees with career planning and skills development. Some organizations fear that career planning will communicate to employees that their jobs are at risk, but it can be framed differently to communicate that they are willing to invest in helping employees reach their potential (Moses, 2000). Companies can also help ease employees' minds by making career planning a standard part of their employee development process rather than introducing it when they know they are going to be facing a period of downsizing or restructuring (Moses, 2000).

In conclusion, much of the recent literature on career development has it that, in today's organizations, there is no longer a guarantee of a career for life in a single institution and individuals who were previously cosseted need to take greater responsibility for their own career development. Traditional approaches to career path analysis and targeted development are breaking down. This trend is borne out as a result of empirical studies into a number of large corporations.

\section{DISCUSSION \\ Employee Performance and Training and Development Activities}

Today, the relationship between the organization and the employee has changed. A greater importance is attached to the value of individuals and the team contributions, to find effective business solutions which play key role towards successful organizational performance through its objectives. The employee is viewed as a 'learning customer', bringing personal preferences and motivation to the workplace, and thereby displaying innovation in his managerial skills. There are positive relationships between training and development and organizational objectives as a measure of performance. In case of learning organizations like Accra Technical University, training has been linked to both strategy plan and organizational performance: training must be aligned to organizational strategy in order to result in high performance 
(Delery and Doty 1996). The strategic formalization of training facilitates organizations to analyze and carry out effective internal and external scanning of their work environments (Lyles, Baird, Orris and Kuratko 1993): clearly defined vision/mission statements and organizational strategies are part of the strategic planning process which contributes towards the development of specific functional strategies needed to achieve business objectives. Strategy formulation is important in the development of HR strategies needed to attract and retain the human capital required for gaining competitive advantage (Poole and Jenkins 1996). Therefore, it is proposed:

Hypothesis 1: Employee performance (job satisfaction, competitive advantage and measurable performance being its levers) will mediate the relationships positively between T\&D activities and organizational objectives.

\section{Training Formalization Including Implementation and Its Evaluation}

The new trends and current business challenges have created the need for strategic approaches to training and development. HRD Department must have the ability to formalize training and development plan, its alignment with the business strategy, and its implementation and evaluation to enhance organizational performance. Training and development does not take place in a void but within specific contexts as perceived by scholars. Many studies demonstrate the importance of understanding the human behaviors. There are human resource practices which are considered important in one scenario but the same may be considered less important in the other We have to understand that at the organizational level, culture, values and work force diversity are major features which affect the relationships between training and development and organizational performance. Similarly, ownership, size, technology and organizational structure are few other features which influence HRD activities and organizational. Therefore, it is proposed:

Hypothesis 2: T\&D formalization including its implementation and evaluation will be positively related to organizational performance.

\section{Learning Organization and its Strategic T\&D Alignment}

Training and development process includes a wide range of learning actions and therefore to develop an organization with a strategic focus, it becomes a model of learning organization. In order to maintain and nurture such organizations, we require strategic focus on the needs of learning, both for the employer and the employee. In order to create a win-win situation both for the organization and the employee, the employer must consider the learner (the employee) as a vital investment for organization's successful performance. In these organizations, a direct linkage between the organization's mission and its learning culture, benefits both the employer and the employee, highlighting the positive associations of learning, motivation and organizational performance. The learning organization therefore requires an environment that supports growth for individual capability and experience and, at the same time, increases business performance. For a learning organization to become effective, it is necessary that leadership support and guidance for continuous learning is vital, specially steered by the CEO. Therefore, it is proposed:

\section{Hypothesis 3: Learning organization and its strategic T\&D alignment will be positively} related to organizational performance.

\section{Training and Development}

\section{Identification of Training and Development Needs}

Management of Accra Technical University are expected to discuss training and development needs with each of their staff at least annually as part of the Performance Review and Planning process in achieving institutional objectives. The training and development needs of staff newly appointed to their positions should be discussed within three to four weeks of their 
taking up the position, whether or not they are new to the organization. However, in Accra Technical University, the case is of the reverse.

\section{Internal Training and Development Sessions}

The Training and Development Unit under the university's registrar organizes training for staff on campus and at times outside the university and sets up specific sessions to meet identified needs for a department or section group of departments, or occupational group.

\section{External Training and Development}

The university sponsored staff attending external courses from time to time. The university may decide to send staff to specific external courses. Depending upon the nature of the course and the time frames, nominations may be sought by the Registrar and Departmental Heads as appropriate. Representation will be decided by the scholarship Committee. Fees (and approved travel and accommodation where applicable) will generally be met from the centralized training budget. Any other incidental costs are the responsibility of the nominating department or section. Staff members supported from this budget are generally expected to submit a brief report to the Registrar, the Vice Chancellor and where appropriate, may be expected to pass on the knowledge and skills gained to a wider group, for example through seminars or workshops.

\section{Training and Development Its Role in Achieving Organizational Objectives}

Is investment in the area of training and development linked to the bottom line within the business. Increasingly, high performing organizations today are recognizing the need to use best training and development practices to enhance their competitive advantage. Training and development is an essential element of every business if the value and potential of its people is to be harnessed and grown. Many studies have highlighted the clear links between well designed and strategic training and development initiatives and the bottom line within the business. The image of an institution and of individual employers is also influenced by the extent and quality of staff training and development. Potential employees in such an open labour market will assess the track record of prospective employers in this vital area. Career Progression and development is an increasingly attractive or even basic requirement for many such employees. In today's business climate where all industries are experiencing staff and skills shortages, companies are faced with stiff internal and external competition for quality employees. Each employer who invests seriously in the area of training and development will reap the benefits of an enriched working environment with higher levels of staff retention as well as increased productivity and performance.

\section{Training and Development Objectives in an Organizational Development}

The types of training and development goals identified will depend on the personal and organizational objectives identified through the strategic planning process and the agreed appraisal procedure. In any event the goals shall, as a minimum standard, take account of the following.

- Continuing personal and professional development

- Equal Opportunities Policy

- Requirements for core competencies

- Requirements for organizational change

- Requirements for professional and vocational qualification in further education

- Requirements for professional, vocational and workplace updating

- The mission

- The strategic objectives of the University

- The Values 


\section{TRAINING AND DEVELOPMENT ANALYSIS AND FINDINGS}

The analysis of the T\&D research revealed that HR's role is to establish and implement a highlevel roadmap for strategic training and development. The strategic positioning of training and development directly promotes organizational business goals and objectives, and thereby enhancing organizational performance. The findings emerged as a result of survey are discussed as under:

- Organizations must focus on continual learning and job trainings in order to achieve their stated objectives

- Registrars, VCs and managers should be involved in policy decisions for training

- Good training must provide opportunities to learn and grow

- Employee Performance is augmented through competitive advantage

\section{CONCLUSION}

There is still a big gap between the knowledge and skills imparted and acquired in the institutions and its applications as seen in the industrial environments. Due to this gap, organizations now feel that there should be a close liaison between such institutions and the industry so that employee development programs are made more purpose oriented. There are training institutions which offer customized as well as off-the-shelf programs based on their client's business operations but yet, there is much to be improved. Therefore, training and development cannot be disconnected from the business activities of the organizations; on the contrary, this is the area that clearly illustrates positive relationships between training activities and the organizational objectives. In particular it is recognized that an effective training and development policy can be a crucial factor in addressing inequalities in employment in relation to race, gender and disabilities. It is recommended that organization produce a training and development plan, the aim of which shall be to empower all employees to carry out their roles to the highest standards, and deliver high quality services to customers based on the organizational objectives. In these, training and development are broadly defined as those activities aimed at raising the standards of employee practice and thus lifting the quality of the employees, and customers learning and organization experiences.

\section{References}

Byars, L. Lloyd and Rue, W. Leslie (1991) Human Resource Management, 3rd Edition; published by Von Hoffman Press Inc., U.S.A.

Cole, G. A. (1996) Management, Theory and Practice - 5 $5^{\text {th }}$ Edition (Ashford Colour Press - London).

Cuniff, J. (2000, July 26) Lifelong education has become the norm. Milwaukee Journal Sentinel, 35Q.

Fitzgerald, W. (1992). Training versus Development, http://fined article.com

Flippo. Godwin B. (1960) Principles of Personnel Management. First Edition (The Maple Press Company - New Your, USA).

Guest, D. (1997). Human resource management and performance: A review and research agenda. International Journal of Human Resource Management, 8 (3), 263-276.

Huselid, M. A. (1995). The impact of human resource management practices on turnover, productivity, and corporate financial performance. Academy of Management Journal, 38, 635-672.

Longman Group UK Limited (1987). Longman Dictionary of Contemporary English. New Edition. 2 ${ }^{\text {nd }}$ Edition. Longman. 1229p.

Mahoney, T., \& Watson, M. (1993). Evolving modes of work force governance: An evaluation, in Kaufman, B. et al (eds), Employee representation: Alternatives and future directions, Ithaca, NY: ILR Press.

Majchrzak, A. (1988). The Human slide of factory automation, San Francisco, CA: Jossey-Bass.

McNamara, C. (2008). Employee Training and Development: Reasons and Benefits. Copyright 1997-2008. 9p.

Moorhead and Griffin (1998) Organizational Behaviour, $5^{\text {th }}$ Edition 
Moses, B. (1999, February 1). Career planning mirrors social change. The Globe and Mail [On-line]. Retrieved January 18, 2001 from the World Wide Web: http://www.bbmcareerdev.com/careerplan.html

Noe, R.A. [2006]. Employee Training and Development, $4^{\text {th }}$ Edition, McGraw-Hill/Irwin. 552p

Nunn, J. (2000, September/October). Career development planning key to employee retention. Journal of Property Management, 65 (5), 20-21.

O'Herron, P., \& Simonsen, P. (1995, May). Career development gets a change at Sear Credit. Personnel Journal, 74 (5), 103-106.

Storey, J. (1987). New perspective on human resource management, London: Routledge and Kegan Paul. 6p.

Storey, J. (1995). (ed) Human resource management: A critical text. London: Routledge. 35p.

Turkson, J. K., (1994) Business Management for Senior Secondary Schools, Longman Group Limited, 122 pp. Jakentee Publication - Kumasi

Tyson, S. (1997). Human resource strategy: A process for managing the contribution of HRM to organisation performance, The International Journal of Human Resource Management, 8 (3), 277-290.

Weatherly, J. (ed) (2000). Oxford Advance Learner's Dictionary of Current English. $6^{\text {th }}$ Edition. Oxford University Press. 2000. 1428p. 